\title{
EDUKASI PENINGKATAN INFORMASI MENGENAI PENYAKIT HIPERTENSI PADA MASA PANDEMI COVID-19
}

\author{
Novendy ${ }^{1}$, Shynta Amelia ${ }^{2}$, Wilson Kristianus ${ }^{3}$, Susy Olivia Lontoh ${ }^{4}$ \\ ${ }^{1}$ Bagian Ilmu Kesehatan Masyarakat, Fakultas Kedokteran Universitas Tarumanagara, Jakarta \\ Surel: novendy@fk.untar.ac.id \\ ${ }^{2}$ Mahasiswa Program Studi Profesi Dokter, Fakultas Kedokteran Universitas Tarumanagara, Jakarta \\ Surel: shynta0104@gmail.com \\ ${ }^{3}$ Mahasiswa Program Studi Profesi Dokter, Fakultas Kedokteran Universitas Tarumanagara, Jakarta \\ Surel: wilsonkristianus@yahoo.com \\ ${ }^{4}$ Bagian Ilmu Faal, Fakultas Kedokteran Universitas Tarumanagara, Jakarta \\ Surel: susyo@fk.untar.ac.id
}

\begin{abstract}
The COVID-19 pandemic has caused restrictions on activities, and it has the potential to increase the prevalence of non-communicable diseases for people with risk factors. Hypertension is a non-communicable disease which is still a health problem in Indonesia. Therefore, it is necessary to educate the public to increase awareness of the occurrence of hypertension. The method was used to provide health education to the community. The success of this activity was assessed from the results of the pretest and posttest. The health service activity was held on October 2, 2021 and was attended by 38 participants. The average value of the pretest results was 23.68 points and the posttest score was 70.18 points. This shows an increase in the average posttest value of 3 times the average value of the pretest. Participants with poor knowledge in pretest were 36 (94.8\%) participants. The result dropped to 7 (18.4\%) participants after the posttest. While only $1(2.6 \%)$ participants with good knowledge in the results of the pretest and increased to $13(34.2 \%)$ participants from the posttest results. The results of this activity have been proven to increase participants' knowledge about hypertension. This is reflected in the decrease in participants with poor knowledge and an increase in participants with good knowledge. It is hoped that these results can increase public awareness of the dangers of hypertension so that it can avoid the occurrence of hypertension in the future.
\end{abstract}

Keywords: hypertension, education

\begin{abstract}
ABSTRAK
Masa pandemi covid-19 menyebabkan terjadi pembatasan aktifitas di luar rumah sehingga berpotensi meningkatkan prevalensi orang dengan faktor risiko penyakit tidak menular. Hipertensi termasuk penyakit tidak menular yang sampai saat ini masih menjadi masalah kesehatan di Indonesia. Maka dengan itu perlu dilakukan edukasi kepada masyarakat untuk meningkatkan kewaspadaan terhadap terjadinya penyakit hipertensi. Metode yang digunakan dalam kegiatan bakti kesehatan ini adalah dengan memberikan edukasi berupa penyuluhan kepada masyarakat. Keberhasilan kegiatan ini dinilai dari hasil pretes dan postes. Kegiatan bakti kesehatan dilaksanakan pada tanggal 02 Oktober 2021 dan diikuti oleh sebanyak 38 peserta. Nilai rata-rata dari hasil pretes adalah 23.68 poin dan nilai ratarata postes adalah 70.18 poin. Hal ini menunjukkan adanya peningkatan nilai rata-rata postes sebesar 3 kali dari nilai rata-rata pretes. Peserta dengan hasil pengetahuannya kurang dari pretes adalah sebanyak $36(94.8 \%)$ peserta. Hasil tersebut turun menjadi 7 (18.4\%) peserta setelah postes. Sedangkan hasil pretes hanya didapatkan $1(2.6 \%)$ peserta dengan pengetahuan baik dan meningkat menjadi 13 (34.2\%) peserta dari hasil postes. Hasil kegiatan ini terbukti telah dapat meningkatkan pengetahuan peserta mengenai penyakit hipertensi. Hal ini tercermin dari adanya penurunan peserta dengan pengetahuan kurang dan adanya peningkatan peserta dengan pengetahuan baik. Maka diharapkan dengan hasil ini dapat meningkatkan kesadaran masyarakat akan bahaya penyakit hipertensi sehingga dapat terhindar dari terjadinya penyakit hipertensi di kemudian hari.
\end{abstract}

Kata kunci: hipertensi, edukasi, penyuluhan 


\section{PENDAhUluAN}

Penyakit Covid-19 yang dilaporkan pertama kali di Indonesia sejak 02 Maret 2020 telah memberikan dampak bagi kehidupan banyak orang, baik secara fisk maupun materi. Semakin banyak pasien yang terkonfirmasi positif dan jumlah pasien yang meninggal serta meluasnya cakupan wilayah yang terkena bencana Covid 19 menimbulkan implikasi pada aspek sosial ekonomi yang luas di Indonesia (Susilo et al, 2020). Pemerintah menetapkan penyakit Covid-19 sebagai bencana nasional berdasarkan Keputusan Presiden Republik Indonesia Nomor 12 Tahun 2020 tentang Penetapan Bencana Non Alam Penyebaran Corona Virus Disease 2019 (COVID19) sebagai Bencana Nasional (JDIH BPK RI, 2020).

Selama masa pandemi Covid-19, orang penyandang penyakit tidak menular (PTM) yang selanjutnya merupakan populasi yang sangat rentan terinfeksi, bahkan disertai jumlah kematian yang cukup tinggi. Oleh sebab itu upaya pencegahan dan pengendalian PTM perlu terus diterapkan secara aman dan efektif, dalam arti meminimalisir risiko dan dampak penularan Covid-19 baik bagi petugas maupun masyarakat yang dilayani (Kemenkes RI, 2020).

Penyakit tidak menular menyebabkan kematian pada sekitar 41 juta jiwa tiap tahunnya (WHO, 2021). Berdasarkan kondisi diatas perlu adanya kontrol dan pencegahan PTM sehingga dengan pencegahan PTM dapat berkontribusi pada perbaikan kualitas hidup dan harapan hidup (Chaker et al, 2015; WHO, 2021).

Pada masa pandemi terjadi pembatasan kegiatan/aktifitas diluar rumah, sehingga berpotensi meningkatkan prevalensi orang dengan faktor risiko PTM. Hipertensi termasuk dalam PTM yang sampai saat ini masih menjadi masalah kesehatan dan menjadi perhatian bagi masalah kesehatan di Indonesia. Berdasarkan data Riset Kesehatan Dasar tahun 2018 berdasarkan hasil pengukuran tekanan darah prevalensi hipertensi di Indonesia masih tinggi yaitu sebesar 34,1 \% pada penduduk usia 18 tahun ke atas (Kemenkes RI, 2018).

Hipertensi adalah peningkatan tekanan darah sistolik lebih dari normal yaitu $140 \mathrm{mmHg}$ dan tekanan darah diastolik lebih dari $90 \mathrm{mmHg}$ pada dua kali pengukuran dengan jarak waktu lima menit dalam keadaan tenang atau cukup istirahat (PERHI, 2019; Kemkes RI, 2014). Hipertensi merupakan salah satu penyebab utama mortalitas dan morbiditas di Indonesia, sehingga pengendalian hipertensi dapat dilakukan sedini mungkin sehingga hipertensi dapat dikendalikan (Kemkes RI, 2014).

Hipertensi dapat dikontrol melalui gaya hidup yang baik, kurangnya kesadaran masyarakat akan kesadaran mengubah pola hidup memperparah kondisi penderita hipertensi. Pilihan yang baik dalam peningkatan informasi mengenai penyakit hipertensi dapat tercapai melalui kegiatan promosi kesehatan melalui komunikasi, informasi, dan edukasi (Nuraeni, Mirwanti \& Anna, 2017). Masyarakat perlu memahami langkah-langkah pencegahan hipertensi karena hipertensi merupakan salah satu penyakit penyerta paling banyak dialami pasien Covid-19 yang meninggal dunia.

Ketidaktahuan dan masih banyak masyarakat yang sadar dirinya telah memiliki faktor risiko namun tidak peduli terhadap kondisi hipertensi yang dialaminya karena penderita hipertensi seringkali tanpa disertai keluhan dan gejala yang mengganggu. Pemberian informasi dan edukasi pada masyarakat terkait hipertensi merupakan upaya untuk meningkatkan pengetahuan, kesadaran, dan keinginan masyarakat dalam mencegah dan melakukan perawatan tekanan darah di rumah, sehingga tekanan darah dapat tetap terkontrol dengan baik ataupun pencegahan terhadap komplikasi akibat hipertensi terutama pada masyarakat yang berisiko. Maka dengan itu, diperlukan suatu kegiatan bakti kesehatan sebagai bentuk penyampaian informasi mengenai 


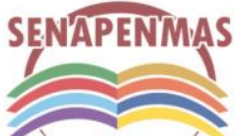

2021
Seminar Nasional Hasil Penelitian dan Pengabdian Kepada Masyarakat 2021

Pengembangan Ekonomi Bangsa Melalui Inovasi Digital Hasil Penelitian dan Pengabdian Kepada Masyarakat Jakarta, 21 Oktober 2021

hal-hal yang berkaitan dengan penyakit hipertensi ini. Sehingga masyarakat akan semakin sadar dan peduli akan bahaya penyakit hipertensi dan dapat mencegah jangan sampai terjadi penyakit tersebut. Dan bila sudah terjadi hipertensipun, masyarakat dapat tetap menjaga jangan sampai terjadi komplikasi dikemudian hari.

\section{METODE PELAKSANAAN PKM}

Metode yang digunakan pada kegiatan bakti kesehatan dalam periode ini adalah pemberian edukasi mengenai penyakit hipetensi. Bentuk kegiatan edukasi yang dilakukan adalah menggunakan penyuluhan secara daring (online) kepada masyarakat, hal ini dilakukan karena dengan memperhatikan kondisi saat ini yang masih dalam pandemi penyakit Covid-19. Peserta dalam kegiatan bakti kesehatan ini adalah masyarakat Kelurahan Tomang yang dimana merupakan daerah binaan. Keberhasilan dari kegiatan bakti kesehatan ini adalah adanya peningkatan pengetahuan masyarakat mengenai penyakit hipertensi. Peningkatan pengetahuan ini dinilai melalui hasil pretes dan postes yang diberikan kepada masyarakat yang dibagi menjadi pengetahuan baik, cukup dan kurang berdasarkan kriteria yang ditentukan oleh Arikunto.

\section{HASIL DAN PEMBAHASAN}

Kegiatan bakti kesehatan dilaksanakan pada tanggal 02 Oktober 2021 secara daring dengan menggunakan aplikasi zoom meeting. Kegiatan dimulai pada pukul $09.00 \mathrm{WIB}$ diawali dengan pembukaan dan peserta diminta untuk mengisi pretes terlebih dahulu. Setelahnya kegiatan edukasi dimulai. Topik mengenai waspada hipertensi dibawakan oleh dokter muda Synthia Amelia. Selain menjelaskan mengenai apakah itu penyakit hipertensi, juga diputarkan video mengenai penyakit hipertensi. Hal ini untuk mempermudah juga peserta memahami apakah itu penyakit hipertensi.
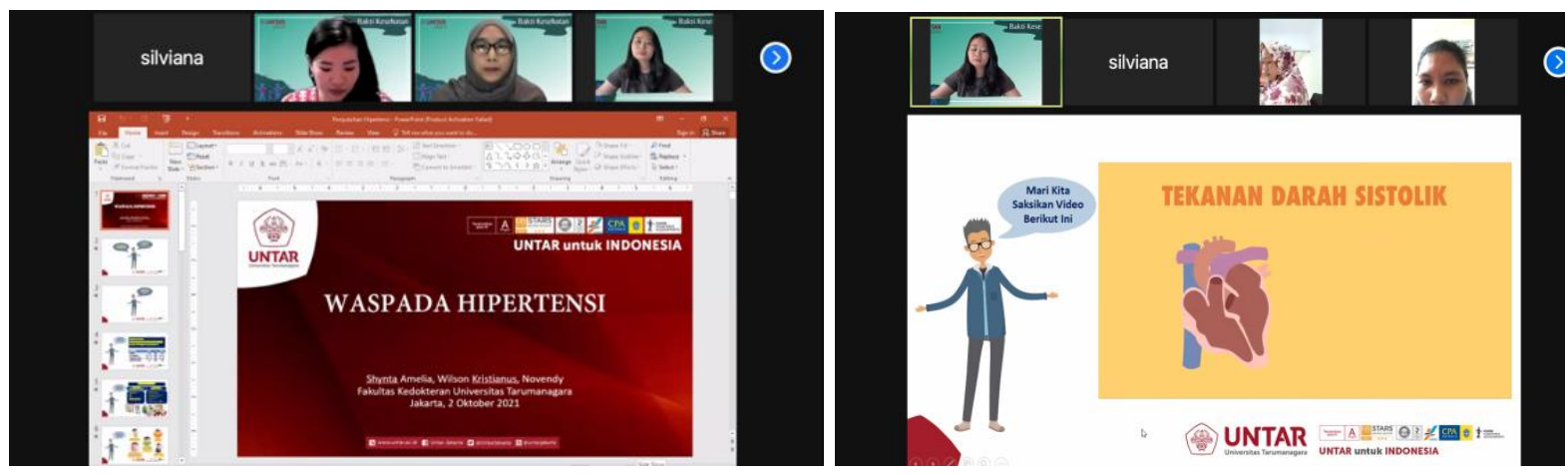

Gambar 1. Penyampaian materi oleh dokter muda Shyntia Amelia (Sumber: Dokumentasi Penulis, 2021)

Urutan pertama dalam upaya pencegahan penyakit menurut Leavell dan Clark adalah promosi kesehatan. Promosi kesehatan menurut World Health Organization yang dikutip oleh Notoatmodjo adalah suatu proses meningkatkan kemampuan masyarakat dalam meningkatkan dan memelihara kesehatannya untuk mencapai derajat kesehatan yang sempurna baik fisik, mental dan sosial (Notoadmodjo, 2018). Sehingga dalam kegiatan bakti kesehatan ini, dilakukan edukasi yang merupakan salah satu bentuk promosi kesehatan kepada masyarakat. Hal ini dikarenakan dengan memberikan informasi tentang penyakit hipertensi diharapkan masyarakat dapat lebih mengetahui mengenai penyakit ini, sehingga meningkatkan kewaspadaan terhadap penyakit hipertensi. 
Sebanyak 38 orang peserta yang berpartisipasi dalalm kegiatan bakti kesehatan ini. Rata-rata usia peserta yang ikut dalam kegiatan bakti kesehatan ini adalah 39.68 tahun dengan rentang usia antara 18 - 59 tahun. Dari 38 peserta yang berpartisipasi didapatkan sebanyak $11(29 \%)$ peserta berjenis kelamin laki-laki dan sebanyak 27 (71\%) peserta berjenis kelamin perempuan. Tingkat pendidikan terakhir peserta yang paling banyak adalah peserta dengan tamat SMA, yaitu sebanyak $28(74 \%)$ peserta.

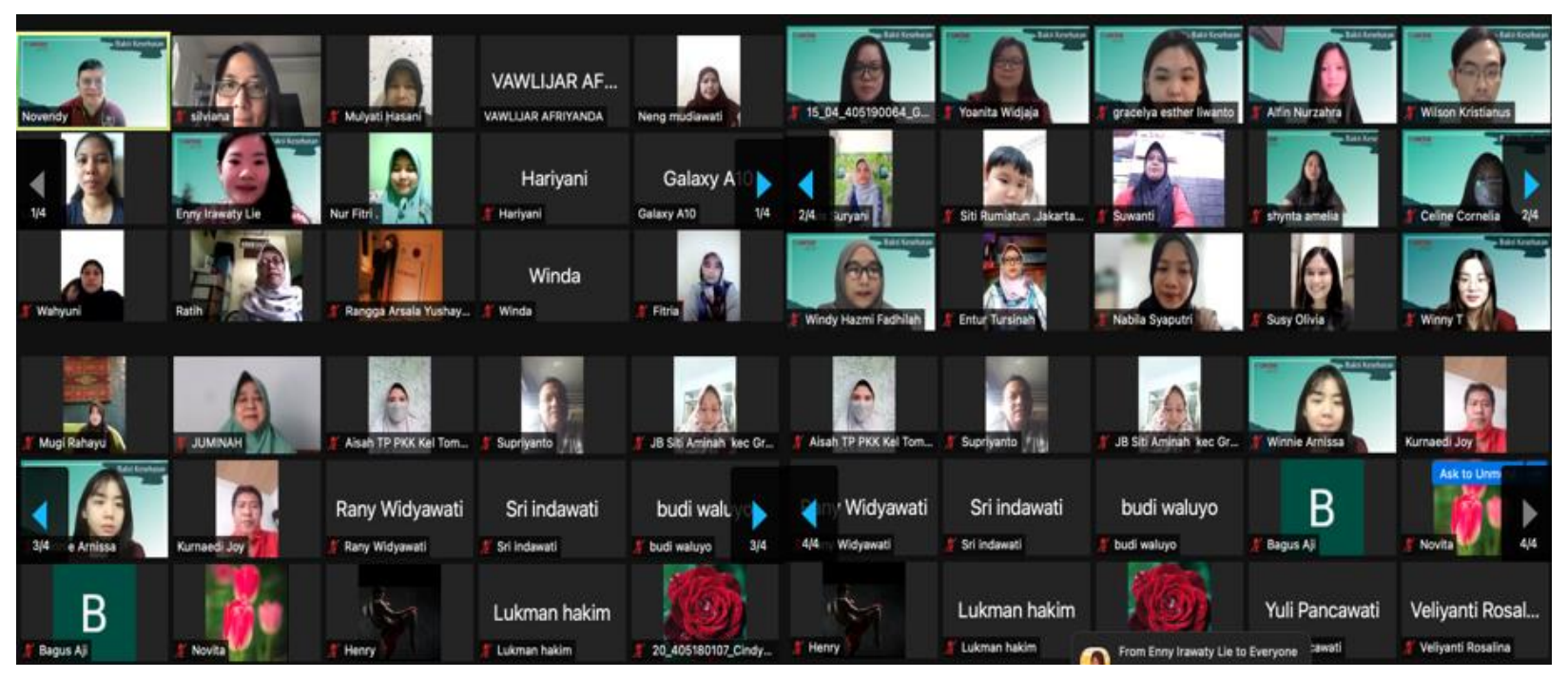

Gambar 2. Peserta Kegiatan Bakti Kesehatan

(Sumber: Dokumentasi Penulis, 2021)

Hasil pretes dari kegiatan bakti kesehatan ini didapatkan nilai rata-rata sebesar 23.68 dan hasil postes didapatkan rata-rata sebesar 70.18. Hal ini menunjukkan adanya peningkatan nilai ratarata postes hampir 3 kali dibandingkan nilai rata-rata pre tes. Tingkat pengetahuan seseorang dapat diketahui dan diinterpretasikan dalam suatu skala kualitatif. Skala tersebut menurut Arikunto yang dikutip oleh Wawan dan Dewi dibagi menjadi: baik, bila hasil persentase 76\%100\%; cukup, bila persentase 56\%-75\%; dan kurang, bila hasil persentase < 56\% (Wawan \& Dewi, 2016). Berdasarkan pembagian tersebut, maka diperoleh hasil bahwa pada hasil prestes didapatkan hampir seluruh peserta memiliki pengetahuan yang rendah mengenai hipertensi, yaitu sebanyak 36 (94.8\%) peserta. Namun setelah dilakukan edukasi, hasil postes menunjukkan hasil yang sangat baik, yaitu peserta yang memiliki pengetahuan kurang turun menjadi hanya tinggal 7 (18.4\%) peserta. Hal ini cukup sejalan dengan hasil yang didapatkan dari Widianingrum dan Dewi, dimana frekuensi pengetahuan kurang mengenai hipertensi pada responden usi 45-60 tahun adalah 80\% (Widianingrum \& Dewi, 2013). Sedangkan yang pengetahuan baik yang sebelumnya hanya 1 (2.6\%) peserta, naik menjadi 13 (34.2\%). Hal ini berbeda dengan hasil dari Widianingrum dan Dewi, dimana setelah penyuluhan seluruh (100\%) responden pengetahuannya meningkat menjadi pengetahuan baik. Hal ini mungkin dikarenakan adanya perbedaan jumlah soal yang digunakan dan jenis pertanyaan yang diajukan. Namun dalam kegiatan bakti kesehatan tetap menunjukkan peningkatan pengetahuan yang sangat baik. Data pengetahuan peserta selengkapnya dapat dilihat pada Tabel 1. 
Tabel 1. Distribusi pengetahuan peserta mengenai penyakit hipertensi.

\begin{tabular}{lcccc}
\hline Variabel & \multicolumn{2}{c}{ Hasil Kegiatan } & \multicolumn{2}{c}{ Postes } \\
& \multicolumn{2}{c}{ Pretes } & \multicolumn{2}{c}{ N=38 } \\
& Jumlah & Persentase $(\%)$ & Jumlah & Persentase $(\%)$ \\
\hline Pengetahuan kurang & 36 & 94.8 & 7 & 18.4 \\
Pengetahuan cukup & 1 & 2.6 & 18 & 47.4 \\
Pengetahuan baik & 1 & 2.6 & 13 & 34.2 \\
\hline
\end{tabular}

\section{KESIMPULAN DAN SARAN}

Hasil kegiatan bakti kesehatan ini didapatkan hasil peningkatan pengetahuan yang sangat baik, dimana peserta pada saat pretes mendapatkan hasil dengan pengetahuan kurang sebanyak 26 $(94,8 \%)$ peserta berkurang menjadi tinggal 7 (18.4\%) peserta pada saat postes. Hanya $1(2.6 \%)$ peserta yang pengetahuannya cukup pada saat pretes meningkat menjadi sebanyak $18(47.4 \%)$ peserta pada hasil postes. Dan terdapat sebanyak $1(2.6 \%)$ yang pengetahuannya baik pada saat pretes, meningkat menjadi $13(34.2 \%)$ peserta dengan pengetahuan baik pada hasil postes. Adapun peningkatan pengetahuan ini dapat dilihat dari hasil rata-rata nilai pretes dan postes. Dimana nilai rata-rata pretes sebesar 23.68 meningkat menjadi 70.18 pada hasil postes. Hal ini menunjukkan adanya peningkatan nilai rata-rata postes hampir 3 kali dibandingkan nilai rata-rata pre tes. Dengan peningkatan pengetahuan ini diharapkan peserta dapat semakin sadar akan faktor-faktor yang dapat menimbulkan penyakit hipertensi sehingga dapat lebih memperhatikan faktor tersebut dan tidak terjadi penyakit hipertensi di kemudian hari.

\section{Ucapan Terima Kasih}

Dalam kesempatan ini, tim mengucapkan terima kasih kepada Lembaga Penelitian dan Pengabdian kepada Masyarakat Universitas Tarumanagara yang telah mendanai kegiatan bakti kesehatan ini. Ucapan terima kasih juga disampaikan kepada seluruh peserta telah berpartisipasi dalam kegiatan ini. Terima kasih juga disampaikan kepada Pimpinan Universitas Tarumanagara beserta Pimpinan Fakultas Kedokteran Universitas Tarumanagara atas dukungannya dalam pelaksanaan kegiatan ini.

\section{REFERENSI}

Chaker, L., Falla, A., Van der Lee, S., Muka, T., Imo, D., Jaspers, L., Franco, O. H. (2015). The global impact of non-communicable disease on macro-economic productivity: a systematic review. European Journal of Epidemiology, 30(5):357-395. DOI: https://doi.org/10.1007/s10654-015-0026-5.

JDIH BPK RI. (2020). Keputusan Presiden (KEPPRES) tentang Penetapan Bencana Nonalam Penyebaran Corona Virus Disease 2019 (COVID-19) Sebagai Bencana Nasional. Diakses dari: https://peraturan.bpk.go.id/Home/Details/135718/keppres-no-12-tahun-2020.

Kementerian Kesehatan Republik Indonesia (Kemkes RI). (2014). Hipertensi. Jakarta: Pusat Data dan Informasi Kementerian Kesehatan Republik Indonesia. Diakses dari: https://pusdatin.kemkes.go.id/resources/download/pusdatin/infodatin/infodatinhipertensi.pdf. 
Kementerian Kesehatan Republik Indonesia (Kemkes RI). (2018). Potret Sehat Indonesia dari Riskesdas 2018. Diakses dari: https://www.kemkes.go.id/article/view/18110200003/potretsehat-indonesia-dari-riskesdas-2018.html

Kementerian Kesehatan Republik Indonesia (Kemkes RI). (2019). Laporan Riskesdas 2018. Jakarta: Badan Penelitian dan Pengembangan Kementerian Kesehatan Republik Indonesia.

Kementerian Kesehatan Republik Indonesia (Kemenkes RI). (2020). Panduan Adaptasi Kebiasaan Baru Dalam Pencegahan dan Pengendalian Penyakit Tidak Menular. Jakarta: Direktorat Jendral Pencegahan dan Pengendalian Penyakit Tidak Menular Kementerian Kesehatan Republik Indonesia. Diakses dari: https://litbangkespangandaran.litbang.kemkes.go.id/perpustakaan/index.php?p=show_detail \&id $=3785$.

Notoatmodjo, S. (2018). Promosi Kesehatan dan Perilaku Kesehatan. Jakarta: Rineka Cipta. Hh 17-50.

Nuraeni, A., Mirwanti, R., \& Anna, A. (2017). Upaya Pencegahan Dan Perawatan Hipertensi Di Rumah Melalui Media Pembelajaran Bagi Masyarakat Di Kabupaten Pangandaran. Jurnal Pengabdian Kepada Masyarakat, 1(3): 174-178. Diakses dari: http://jurnal.unpad.ac.id/pkm/article/viewFile/16389/7969.

Perhimpunan Dokter Hipertensi Indonesia (PERHI). (2019). Konsensus Penatalaksanaan Hipertensi 2019.2 Diakses dari: http://faber.inash.or.id/upload/pdf/article_Update_konsensus_201939.pdf.

Susilo, A., Rumende, C. M., Pitoyo, C. W., Santoso, W. D., Yulianti, M., Herikurniawan, ... Yunihastuti, E. (2020). Coronavirus Disease 2019: Tinjauan Literatur Terkini. Jurnal Penyakit Dalam Indonesia, 7(1), 45-67. DOI: http://dx.doi.org/10.7454/jpdi.v7i1.415.

Wawan, A \& Dewi, M. (2016). Teori \& pengukuran pengetahuan sikap dan perilaku manusia. Yogyakarta: Nuha Medika.

Widianingrum, R \& Dewi, H. (2012). Efektifitas Penyuluhan Tentang Hipertensi pada Masyarakat Rentang Usia 45-60 Tahun Dibandingkan dengan Masyarakat Rentang Usia 6175 Tahun. Jurnal Kedokteran Muhammdiyah Universitas Muhammadiyah Semarang, vol. 1 (3):86-92. Diakses dari: https://jurnal.unimus.ac.id/index.php/kedokteran/article/view/1353

World Health Organization (WHO). (2021). Non Communicable Disease. Retrieved from: https://www.who.int/news-room/fact-sheets/detail/noncommunicable-diseases. 